\title{
'At school I got myself a certificate': HIV/AIDS Orphanhood and Secondary Education: a Qualitative Study of Risk and Protective Factors
}

\author{
Jocelyn Anstey Watkins • Olga Moleboneng Sello • \\ Lucie Cluver • Lauren Kaplan • Mark Boyes
}

Published online: 5 August 2014

(C) Springer International Publishing 2014

\begin{abstract}
Secondary school is a period during which risk of school dropout is highest. To date, little research has examined reasons for school dropout amongst HIV/ AIDS-orphaned children, who are affected economically, psychosocially and educationally. HIV/AIDS orphanhood can perpetuate poverty and increase school dropout in a range of ways, including inability to pay school fees, family disruption and stigma. Related research mostly focuses on school performance and completion and, more recently, on context-specific approaches to measure educational outcomes. The primary aim of this qualitative study was to examine how HIV/AIDS orphanhood influences participation in secondary education in South Africa and to investigate why some HIV/AIDS-orphaned adolescents find it easier to stay in school than others. Specifically, the study aimed to explore, interpret and elicit the perceptions of South African HIV/AIDSorphaned adolescents $(N=243$, aged 13-22, $53 \%$ female, $47 \%$ male) towards potential risk and protective factors influencing their secondary school attendance. Findings suggest complex and interconnecting multiple risk factors
\end{abstract}

\footnotetext{
J. A. Watkins $(\bowtie) \cdot$ L. Cluver $\cdot$ L. Kaplan $\cdot$ M. Boyes

Centre for Evidence-Based Intervention, Department of Social Policy

and Intervention, University of Oxford, Barnett House, 32

Wellington Square, Oxford OX1 2ER, UK

e-mail: jotawatkins@gmail.com

L. Cluver

e-mail: lucie.cluver@spi.ox.ac.uk
}

O. M. Sello

Health Economics and HIV/AIDS Research Division (HEARD),

University of Kwa-Zulu Natal, Kwa-Zulu Natal, South Africa

\section{Boyes}

Health Psychology and Behavioural Medicine Research Group, School of Psychology and Speech Pathology, Curtin University, Perth, Australia such as poverty pre- and post-parental death, crisisfosterage often accompanied by further traumatic events, changing schools sporadically, recurring household migration and forced employment all of which can create obstacles to secondary education. Protective factors that emerged included extra-curricular activities and teacher/ community support. These findings highlight the need for evidence-informed school and community policies, which consider the effects of household poverty, migration and living arrangements, if secondary school participation for HIV/AIDS-orphaned adolescents is to be promoted and sustained.

Keywords South Africa · HIV/AIDS · Adolescents · Orphanhood $\cdot$ Secondary school $\cdot$ Education

\section{Introduction}

My mother died. My stepfather chased us away from the house with my brother. I dropped out of school because there's no one who can take me to school. I have no money for school, even for food. (Bantubonke [all names have been changed throughout to ensure anonymity], 16-year-old male).

Duffy (2005) argues that HIV/AIDS is the most insidious disease this century has encountered, posing the single greatest challenge to Africa's marginalised poor, where it has found 'a malnourished, vulnerable, defenceless host' (Odhiambo 2003). Nearly one third of South Africa's population is under the age of 15 (StatsSA 2011) and approximately $18 \%$ of young people between the ages of 15-24 are HIV+ (UNAIDSa 2013). In 2013, the Joint United Nations 
Programme on HIV/AIDS (UNAIDS 2013) reported an estimated 17.8 million children having lost one or both parents to AIDS, of which $85 \%$ of those children resided in sub-Saharan Africa. These children are captured by the United Nations Children's Fund (UNICEF 2011) definition of orphans and vulnerable children (OVC), i.e. children who have lost one or both parents and/or those residing with a chronically ill adult in the same household.

The direct and indirect psychosocial effects of HIV/ AIDS on adolescents are extensively documented (Van Blerk \& Ansell 2006). Often HIV/AIDS-orphaned adolescents are stigmatised by the community for being HIV positive and for taking care of bedridden AIDSsick parents. Boyes \& Cluver's (2013) recent paper demonstrates how long-term stigmatisation can mediate the relationships between AIDS orphanhood and mental health. Increased access to antiretroviral medication creates longer-term duties of care (Skovdal et al. 2009). Caregiving arrangements pose major challenges to society after the death of an economically productive family member (Odhiambo 2003) often leading to poor welfare, which threatens the aspirations of a child's educational advancement (Foster 2006; Bicego et al. 2003).

The provision of educational opportunity is considered one of the key components of the current 'safety-net' for OVCimpacted communities (Hunter \& Williamson 2000) where schools can be supportive social spaces (Campbell et al. 2010). Children feel much safer when they are in a comfortable family and community environment. However, evidence suggests that negative associations exist between HIV prevalence and school enrolment (Ardington \& Leibbrandt 2010). Furthermore, HIV/AIDS-orphaned children are significantly more likely to be delayed in school in comparison to children not orphaned by AIDS (Cluver et al. 2011a, 2011b).

A major consequence of poor school attendance is that educational attainment begins to deteriorate even before children are orphaned. After parental death, the family structure erodes further, problematizing children's life conditions and educational opportunities (Bicego et al. 2003). Qualitative studies suggest that when families can no longer cope due to the debilitating effects of AIDS, sometimes girls and older children leave school to help with domestic work (Masanjala 2007) and provide care for AIDS-sick relatives (Booysen \& Arntz 2002). Regular absenteeism becomes common, creating a self-propagating cycle of non-attendance. Multiple evidences suggest that unaffordable school fees and uniforms are primary causes of non-attendance, which is correlated with poverty (Edmonds 2006) due to decreasing family incomes. Educational disadvantage often includes late arrival, lack of concentration, low school performance and resignation of career aspirations (Orkin et al. 2014).

The literature, focusing on primary school access, suggests that there are several potential risk factors that may cause educational barriers for HIV/AIDS-orphaned children. A recent review by Guo et al. (2012) has identified several potential risk factors such as poverty, caregiving arrangement migration to facilitate caregiving, the caregiving role of grandparents, young carers, AIDS-related stigma, domestic or sexual abuse, child's poor health, psychological problems, HIV risk and teenage pregnancy. Teenage childbearing coincides with the late stages of secondary schooling; therefore, the education of the adolescent mother is likely to be directly impacted by the birth (Branson et al. 2013).

AIDS orphanhood can further exacerbate already-poor educational trajectories. To facilitate caregiving of AIDSaffected family members, migration involves the resettlement of orphans causing major school disruption such as a change of peers and even grade (Ansell \& Van Blerk 2004) and, at worst, not restarting school (Cluver \& Gardner 2007). It has been observed in the literature that the reduced likelihood of HIV/AIDS-orphaned adolescents completing primary or secondary education is associated with multiple indicators of disadvantage including race, gender, geographic location and household characteristics. This is especially problematic because not completing secondary schooling is a major risk factor for contracting HIV (Gavin et al. 2006; Cluver et al. 2011a, 2011b) and other physical and mental ill healths. Indeed, the association between AIDS orphanhood and poor psychological health is mediated through poverty and stigma (Cluver et al. 2008; Petersen et al. 2010). This suggests that poverty and HIVrelated stigma are problematic for an adolescent's health and may also affect educational outcomes.

Few studies have used qualitative research to examine HIV/AIDS-orphaned adolescents' perceptions of secondary education. There is also a scarcity of evidence on protective factors for education of HIV/AIDS-orphaned adolescents. Schools can be an invaluable source of support for children (Murray 2010) providing stability, institutional affiliation and the normalisation of experience (Richter 2004) (although this does not necessarily mean children will remain in school). Cluver \& Gardner (2007) have found that educational assistance, caregivers' attendance at school meetings and completing homework were perceived as protective factors to psychological well-being, but it is not known whether these factors are associated with better educational outcomes.

This exploratory research aims to identify both potential risk and protective factors contributing to HIV/AIDSorphaned adolescents' secondary schooling. The study aims to contribute to informing policy and evidence-based interventions to improve educational opportunity for HIV/AIDSorphaned adolescents. Current research is concerned with primary school attendance (Moleni 2008) and completion, and may not translate to adolescents' secondary schooling, 
where potentially different risk and protective factors for adolescents' attendance or non-attendance may be involved.

\section{Methods}

Participants

Qualitative data was collected in the second phase of a longitudinal study (Cluver et al. 2007, 2012, for a more detailed description of the larger study). Two hundred and forty three single and double HIV/AIDS-orphaned adolescents aged 13$22(M=17.12, \mathrm{SD}=2.73)$, whose mother and/or fathers had died more than 6 months previously (as an additional focus of the study was on adolescent mental health, this was done to exclude acute bereavement reactions) took part in the study. Socio-demographic characteristics of the sample are summarised in Table 1.

All participants were amaXhosa indigenous Africans living in highly deprived neighbourhoods of Cape Town, in the Western Cape. Recruitment was administered through doorto-door community sampling of 20 communities: 10 settlements, 9 schools and 18 community organisations (Boyes et al. 2012). Non-school-based sampling ensured inclusion of young people who were not attending or had left school or street children. To determine AIDS orphan status and parental cause of death, a 16-item verbal autopsy questionnaire was used to classify orphanhood status because death certificates are unreliable sources regarding HIV/AIDS in South Africa, and clinical data is rarely available. The questionnaire has been validated in previous studies in South Africa (Hosegood et al. 2004) as well as in other African countries. In a South African validation study, sensitivity was found to be $89 \%$, specificity $93 \%$ and positive predictive value $76 \%$ (Kahn et al. 2000). Determination of AIDS-related death required identification of three or more AIDS-defining illnesses (i.e. Kaposi's sarcoma, HIV-wasting syndrome, oral candidiasis). Children were not directly asked about their own HIV status, although some chose to discuss this with interviewers. Pseudonyms have been used to ensure confidentiality of participants.

\section{Ethics}

The University of Oxford, The University of Cape Town and The Western Cape Education Department granted ethical approval for the study. Children and caregivers gave informed written consent and research information was given verbally in English and isiXhosa due to low literacy levels. Consent was sought from shelter social workers for street children. Children who reported abuse or harmful circumstances during the study were referred to social services, counselling or helplines.
Table 1 Socio-demographic characteristics of the sample

\begin{tabular}{|c|c|c|}
\hline Variable & Frequency & Proportion $(\%)$ \\
\hline \multicolumn{3}{|l|}{ Orphan type ${ }^{\mathrm{a}}$} \\
\hline Maternal & 89 & 33.6 \\
\hline Paternal & 109 & 41.1 \\
\hline Double & 64 & 24.2 \\
\hline \multicolumn{3}{|l|}{ Dwelling type } \\
\hline Informal structure ${ }^{\mathrm{b}}$ & 101 & 38.1 \\
\hline Formal structure ${ }^{\mathrm{c}}$ & 161 & 60.8 \\
\hline \multicolumn{3}{|l|}{ School attendance ${ }^{\mathrm{d}}$} \\
\hline Full attendance in the last week & 160 & 60.6 \\
\hline Partial or no attendance in the last week & 104 & 39.4 \\
\hline \multicolumn{3}{|l|}{ School years behind ${ }^{\mathrm{e}}$} \\
\hline Less than 2 years behind & 189 & 71.3 \\
\hline More than 2 years behind & 75 & 28.3 \\
\hline
\end{tabular}

In South Africa, it is common that learners over the age of 18 years are still at secondary school because often they enrol late and repeat a school grade. Therefore the term 'adolescents' in this study refers to a schoolgoing learner up to and including 22 years old

a $24 \%$ double orphans, $41 \%$ single paternal orphans

${ }^{\mathrm{b}}$ Shacks made of basic materials often with no electricity and running water

c 'Rural Development Programme - RDP housing' brick/concrete structure or flats

d $39.4 \%$ were attending school partially or not at all during the week preceding interviews

${ }^{\mathrm{e}}$ Signifies how many orphans are not in the correct year group equating to their age: how many have missed school and dropped behind. This variable can be used as a proxy for 'school achievement'

\section{Questionnaire}

Children completed a face-to-face interview with a research assistant (social worker or community health worker trained in child protection and experienced in working with HIV/AIDSaffected children) using a qualitative and quantitative questionnaire lasting 40-60 min. Our analysis focuses on a set of open-ended qualitative questions to elicit individual perspectives on education (Table 2).

\section{Analysis Procedure}

We utilised the inductive technique 'Interpretive Phenomenological Analysis' (IPA) (Smith 2007) that uses codes for organising global themes to aid the identification of a theoretical framework. IPA facilitated the development of hypotheses directly from the experiences of HIV/AIDS-orphaned adolescents and allowed for participant-led identification of needs. The inductive analysis cycle included the following strategies: familiarisation with data, identifying themes, clustering themes and producing a summary table. The 'analytic hierarchy' (Ritchie \& Lewis 2003) involves generating a set of themes according to which the data is sorted and synthesised, 
Table 2 Interview sections and questions

\begin{tabular}{lll}
\hline Catching & How have the past 3 years been for you? \\
Up & Has anything happened that you would like to tell us about? \\
& Home & School \\
Road of life & Whose home were you living in? & What grade are you in now? \\
& Who was the person who looked after you most? & What are the names of your schools? \\
& Why did things change? & Any years you repeated and why? \\
& & When you left school and why?
\end{tabular}

remaining close to the participants' own language and understandings. This hierarchy and 'Thematic Context Analysis' coding framework (Skovdal et al. 2009) were adapted to form an innovative 'Hierarchy of Coding' pyramid to illustrate the pathway of codes to global themes. Both manual and electronic (Nvivo 9) data analysis approaches were utilised.

New emergent themes and the development of existing themes were analysed, interpreted and systematically coded to identify emergent phenomena. By engaging in this analysis, we began to apprehend the educational conundrum that HIV/ AIDS-orphaned adolescents face. Since this is a qualitative analysis, causal explanations relating to the impacts of interacting or cumulative effects of risk and protective factors on adolescents' educational access cannot be argued. However, IPA is an especially useful technique because it commits to understanding how phenomena, event (parental AIDS death), process (bereavement) or relationship (caregiving arrangements) has been understood from the perspective of particular people in a specific context (HIV/AIDS-orphaned adolescent living in poverty and high-crime environments). This detailed examination of human-lived experience allows for the understanding of the meaning that adolescents place on turbulent and/or supportive situations. By engaging in such an analysis, this study focuses on their experiences, which may not otherwise have been heard. Therefore, IPA affords us 'the illuminating perceptive upon personal relationships and processes' (Smith \& Firth 2011). Hypotheses such as early adult responsibility, closeness of caregiver and illness (Operario et al. 2008) were extended into an analytical conceptual framework.

\section{Results}

Our IPA frameworks identified a number of potential risk and protective factors associated with school participation. Risk factors were grouped into seven overarching global themes: poverty, unhappiness at school, caregiving arrangements, emotional distress and suicidal ideation/ attempts, crime and substance abuse, adolescent's health and multiple traumatic events.
Protective factors were grouped into three overarching global themes: happiness at school, caregiving arrangements and community support (Tables 3 and 4).

\section{Risk Factors}

Poverty The majority of HIV/AIDS-orphaned adolescents identified poverty as being the underlying cause in preventing their school attendance. Consistent with previous research, household income was not sufficient to pay school fees, transport costs or purchase school uniforms. 'Even at school I don't eat. I just drink water when the others are eating their lunch. I don't have warm clothes. I feel cold at school.' (Nombulelo, 15-year-old female).

Another participant described being bullied at school because of poverty at home. 'The water comes inside my home. When wind is blowing my home roof comes up. We also cry. Other kids laugh at my home situation. I am also suffering at school.' (Nondumiso, 22-year-old female). Other studies have found a relationship between bullying, mental health and poverty for AIDS-affected children, for example, Boyes \& Cluver (2013) have determined the longitudinal link between HIV/AIDS orphanhood and anxiety/depression, which also operates indirectly via stigma. The distress of being bullied could act as a mechanism for poor mental health possibly leading to school dropout (Boyes et al. 2014; Boyes \& Cluver 2014). Takizawa et al. (2014) found that frequently bullied children had lower educational levels, and men in the labour market were more likely to be unemployed and earn less than their peers without histories of being bullied.

Families with AIDS-ill caregivers or households with only one surviving parent often removed children from school if the main breadwinner was ill or deceased to earn money, which was consistent with Lachman et al. (2013). 'I dropped out of school.... to help my mother sell veggies. Now we eat every day. The veggies are going well' (Nandipha, 17-yearold female). Others exhibited independence by explaining that they were saving their income to return to school in the future.

Unhappiness at School Schools can be locations of AIDSrelated stigma and physical and emotional bullying. In some 
Table 3 Coding framework 1: from codes to global themes: risk factors of educational attendance

\begin{tabular}{|c|c|c|c|}
\hline Codes & Themes identified & Organising themes & Global themes \\
\hline $\begin{array}{l}\text {-Hunger at school and home } \\
\text {-Worrying when next meal will be } \\
\text {-Food parcels cease } \\
\text {-Foster grant cease } \\
\text {-Shack is cold/wet } \\
\text {-Lack of basic necessities } \\
\text {-No school uniform } \\
\text {-Familial unemployment } \\
\text {-Casual weekend jobs } \\
\text {-Started school late } \\
\text {-No money for transport to school } \\
\text {-Homelessness } \\
\text {-School far from home } \\
\text {-Skip school in winter months }\end{array}$ & $\begin{array}{l}\text { 1. Lack of basic school necessities, } \\
\text { fees, food and lack of adequate shelter } \\
\text { 2. Parent may work far from home (away } \\
\text { in the week - as a miner/domestic } \\
\text { worker) } \\
\text { 3. Children seek employment to replace } \\
\text { school to support their family } \\
\text { 4. Breadwinner's jobs are low paid }\end{array}$ & $\begin{array}{l}\text { Poor food security } \\
\text { Lack of clothing } \\
\text { Poor living conditions } \\
\text { Employment }\end{array}$ & Poverty \\
\hline $\begin{array}{l}\text {-Bullying/teasing } \\
\text {-Lunch stolen } \\
\text {-Teacher disliked child } \\
\text {-Failed year-repeat grades } \\
\text {-Dropped out } \\
\text {-Skipped class } \\
\text {-Peer pressure } \\
\text {-Weak at reading/writing } \\
\text {-Found learning difficult }\end{array}$ & $\begin{array}{l}\text { 1. Torment at school because of familial } \\
\text { HIV/AIDS stigma } \\
\text { 2. Peer influence to dropout of school } \\
\text { 3. Lack of interest in secondary school } \\
\text { 4. Underachievement in school subjects }\end{array}$ & $\begin{array}{l}\text { School environment } \\
\text { Child readiness for education }\end{array}$ & Unhappiness at school \\
\hline $\begin{array}{l}\text {-Sleeping in class-tired from domestic chores } \\
\text {-Relocation to foster-carer } \\
\text {-Looked after cattle during the school day } \\
\text {-Abused by guardian emotionally/physically } \\
\text {-Beaten with a belt } \\
\text {-Changed schools } \\
\text {-Foster-carer died } \\
\text {-Cared for AIDS-sick parent } \\
\text {-Missed school to visit parent in hospital } \\
\text {-Stepfather-evicted child, after biological parent } \\
\text { dies of AIDS } \\
\text {-Took younger siblings to school, washed } \\
\text { and fed them } \\
\text {-Child lived on streets } \\
\text {-Child lived in a homestead }\end{array}$ & $\begin{array}{l}\text { 1. Multiple moves - migration to } \\
\text { relatives/guardians } \\
\text { 2. Favouritism by guardian to } \\
\text { biological child- } \\
\text { HIV/AIDS-orphaned child does } \\
\text { more domestic } \\
\text { chores discouraging homework } \\
\text { 3. Duty of care for sick or elderly relative } \\
\text { 4. Looking after younger } \\
\text { siblings-no adult in the household } \\
\text { 5. Increased responsibilities-loss } \\
\text { of childhood }\end{array}$ & $\begin{array}{l}\text { Child being cared for by } \\
\text { foster-carer } \\
\text { Migration-change household } \\
\text { and schools } \\
\text { Secondary orphanhood abuse/ } \\
\text { neglect } \\
\text { Domestic chores } \\
\text { Young carer } \\
\text { Child-headed household }\end{array}$ & $\begin{array}{l}\text { Caregiving arrangements } \\
\text { (negative) }\end{array}$ \\
\hline $\begin{array}{l}\text {-Sad to see AIDS-sick parent } \\
\text {-Painful to dropout of school } \\
\text {-No one to talk to about their feelings } \\
\text {-Felt like killing themselves } \\
\text {-Boredom when not at school } \\
\text {-Separated from siblings }\end{array}$ & $\begin{array}{l}\text { 1. Child recognises suffering around } \\
\text { them } \\
\text { 2. Child's feelings are rarely asked } \\
\text { pre- and post-bereavement } \\
\text { 3. Suicidal thoughts and attempts }\end{array}$ & Suicidal ideation & Emotions \\
\hline $\begin{array}{l}\text {-Electricity money stolen } \\
\text {-Gun and knife crime } \\
\text {-Beaten with bottles } \\
\text {-Burgled in shacks } \\
\text {-Lived in jail for months } \\
\text {-Stabbed a person } \\
\text {-Stole liquor } \\
\text {-Addicted to alcohol, cigarettes } \\
\text { and drugs } \\
\text {-Involved in a gang }\end{array}$ & $\begin{array}{l}\text { 1. Child is a victim of petty crime for } \\
\text { small amounts of money within the } \\
\text { high-crime community or is } \\
\text { physically attacked-goes to hospital. } \\
\text { Incidents make cause child to be } \\
\text { absent from school } \\
\text { 2. Child commits crime for survival, } \\
\text { steals money through armed } \\
\text { robbery/hijackings. Schooling } \\
\text { disrupted if imprisoned }\end{array}$ & $\begin{array}{l}\text { Victims of crime } \\
\text { Perpetrators of crime } \\
\text { Community trauma }\end{array}$ & $\begin{array}{l}\text { Crime and substance } \\
\text { abuse }\end{array}$ \\
\hline
\end{tabular}

Structure of frameworks adapted from (Campbell et al. 2010) 'Coding Framework' and (Skovdal et al. 2009) 'Thematic Context Analysis'

instances, teachers were the cause of distress and were described as contributing to adolescents' disengagement from classroom settings. A recurring theme was repeating the school grade. Failing to pass end-of-year exams was attributed to struggling with learning, poor subject choices or poor peer influences. Many adolescents reported moving to different communities after parental or caregiver deaths. This also meant changing schools during the academic year: some 
adolescents had to begin new subjects and were occasionally taught in a different language than their mother tongue. While in class, feelings of anxiety and worry about AIDS-sick relatives and a future without parents were common. 'Sickness is worrying me very much because when I'm at school I'm always thinking about my mother and what the future holds for us. Her illness has taken place of my studies' (Dumisani, 18-year-old male).

Caregiving Arrangements The quality of care and childguardian relationship was described as important for positive educational outcomes. One negative consequence of kinship care was the foster-carer becoming sick and dying or the adolescent going through secondary orphanhood, where they became re-orphaned leading to multiple moves initiating disruptive schooling. 'My mother died of HIV. There was no one to take care of us so we go to live with a relative. Because my aunt the person we were staying with died, we had to come back to this township and we stayed with my aunt.' (Themba, 16-year-old male).
Caregiving arrangements after parental death were unstable. Reported instances where guardians no longer wanted to care for the orphan-generated instability. They were often left with no permanent home or school. Some adolescents described neglect, physical, emotional and financial abuse by their foster-carer and how this affected their education. 'I was staying with my other aunt who was abusing me. She was drinking alcohol. She insulted me, beat me and sometimes chased me away. Sometimes she refused to give me food. I also failed in grade 10. I was suffering at home so decided to stop school.' (Nomandla, 19-year-old female).

Some caregivers resented HIV/AIDS-orphaned adolescents, blaming them for not having parents. Schooling was discouraged when the foster-carer expected the adolescent to do domestic chores rather than their homework, or when the foster-carer discriminated against the adolescent in favour of their biological children. Some orphans were fostered in order to increase the labour force in the foster family, reducing their chances of attending school because they worked during the school day.

Table 4 Coding framework 2: from codes to global themes: protective factors of educational attendance

\begin{tabular}{|c|c|c|c|}
\hline Codes & Themes identified & Organising themes & Global themes \\
\hline $\begin{array}{l}\text {-Made supportive friends } \\
\text {-Understanding nature of teachers } \\
\text {-Rugby tournaments/football matches } \\
\text {-Taking part in the choir/drama } \\
\text {-Achieving academic certificates } \\
\text {-Being made prefects/captains } \\
\text {-After-school clubs } \\
\text {-School trips to local attractions } \\
\text {-Having hobbies to focus on } \\
\text {-Scholarships or funding from banks } \\
\text {-Getting lunch at school for free }\end{array}$ & $\begin{array}{l}\text { 1. Teacher wants to take care of the child } \\
\text { 2. Sports, extra-curricular activities, school trips } \\
\text { and school food offer an escape from home } \\
\text { life and make the child happy } \\
\text { 3. Gaining awards and recognition of school } \\
\text { achievements } \\
\text { 4. School feeding schemes - free lunch }\end{array}$ & $\begin{array}{l}\text { Peer support } \\
\text { Teacher support } \\
\text { Extra-curricular activities } \\
\text { Sports } \\
\text { Feeding scheme } \\
\text { School awards } \\
\text { Matriculation } \\
\text { Positions of responsibility }\end{array}$ & Happiness at school \\
\hline $\begin{array}{l}\text {-Aunt/grandmother who cared for the } \\
\text { child as if they are their own children } \\
\text {-Community member supported } \\
\text { children by giving them food }\end{array}$ & $\begin{array}{l}\text { 1. Positive and protective guardian care, } \\
\text { in support of child's schooling } \\
\text { 2. Community support for children in } \\
\text { child-headed households }\end{array}$ & $\begin{array}{l}\text { Grandmothers as primary } \\
\text { carer (kinship care) } \\
\text { Community care } \\
\text { (elderly members) }\end{array}$ & $\begin{array}{l}\text { Caregiving arrangements } \\
\text { (positive) }\end{array}$ \\
\hline $\begin{array}{l}\text {-Visiting church with family } \\
\text {-New friendships formed }\end{array}$ & $\begin{array}{l}\text { 1. Religious faith and belief } \\
\text { 2. Friendships with other HIV/AIDS- } \\
\text { orphaned children }\end{array}$ & $\begin{array}{l}\text { Church } \\
\text { Social support }\end{array}$ & Community support \\
\hline $\begin{array}{l}\text {-Physical health-disabled/chest } \\
\text { pains/ear problems } \\
\text {-Became pregnant-left school } \\
\text {-Contracted HIV infection } \\
\text {-Involved in car accidents-hospitalised }\end{array}$ & $\begin{array}{l}\text { 1. Chronic childhood illness } \\
\text { 2. Pregnant by rape or early sexual } \\
\text { debut - teenage motherhood } \\
\text { 3. Child becomes HIV+ } \\
\text { 4. Limited health services available, } \\
\text { traditional healers used }\end{array}$ & $\begin{array}{l}\text { General poor physical health } \\
\text { Pregnancy } \\
\text { Car accidents } \\
\text { HIV+ }\end{array}$ & Children's health \\
\hline $\begin{array}{l}\text {-Burials and funerals } \\
\text {-Raped by 'skollies' (gangsters) } \\
\text {-Unplanned secondary pregnancy } \\
\text {-Abortion or gave child up for adoption } \\
\text {-House burnt down } \\
\text {-Older siblings also died of AIDS } \\
\text {-Younger siblings died of ill health } \\
\text {-Family member committed suicide } \\
\text {-Parents went missing } \\
\text {-Other relatives died of AIDS }\end{array}$ & $\begin{array}{l}\text { 1. Family dispersal—not all orphaned } \\
\text { children can be housed within the same } \\
\text { family — causing distress } \\
\text { 2. Female rape by family member, } \\
\text { acquaintance or gang } \\
\text { 3. Multiple bereavement in a short period of time } \\
\text { 4. Multiple traumatic events directly related to the } \\
\text { child causing further disruption to schooling }\end{array}$ & $\begin{array}{l}\text { Second-generation } \\
\quad \text { orphanhood } \\
\text { Sibling dispersal } \\
\text { Sibling bereavement } \\
\text { Rape }\end{array}$ & Traumatic events \\
\hline
\end{tabular}


Importantly, many HIV/AIDS orphans were responsible for taking care of an AIDS-sick parent, elderly relative or sibling. This parent-child role reversal led to taking time off school to fulfil their duty of care. Teenage male adolescents also discussed caregiving suggesting the role was not always gendered. 'I was staying with my mother. She was sick. Sometimes I was not attending school. I was taking her for treatment or waited at the clinic.' (Sipho, 16-year-old male).

Emotional Distress and Suicidal Ideation and Suicidal Attempts Many children expressed that they felt 'unhappy', 'unloved', 'unwanted' or were 'suffering' with no one to talk to about their feelings. They emphasised how dropping out of school was agonising. Suicidal ideation or attempted suicide between both males and females was relatively high, suggesting severe psychological distress. 'I tried to kill myself. I took an overdose of tablets. I stayed in the streets... I dropped out of school.' (Nomhle, a 20-year-old female).

Crime and Substance Abuse The Western Cape's urban areas, like many of South Africa's densely populated townships, are notorious for substance abuse-fuelled crime. Adolescents described being physically injured as a result of crime, hospitalised for extensive periods and therefore unable to attend school. Some had their shacks burgled, were beaten with bottles or witnessed domestic violence where a relative was shot or stabbed. Some male orphans who were not attending school reported becoming involved in criminal activities, resulting in more time in jail than school. 'I dropped out of school because of poverty and 'gangsterism'.' (Veli, 21year-old male).

Criminal gang culture was deeply related to legal and illegal addictive substances. Some adolescents reported that several family members, especially older male siblings, were also incarcerated. Therefore, the incentive to stay in school was reduced when role models at home were scarce. Parental death often leaves youth with impaired emotional and physical states, and for some, substance abuse reduced their ability to stay in school.

Orphans also discussed being victims of crime, perhaps largely explained by their potential vulnerability of not having a stable and supportive home environment. 'We were robbed by three men in the night while we were sleeping. They took R1000 under the mattress of my eldest brother and they pointed him with a gun. We are now suffering a home, even at school' (Busi, 18-year-old male). The fear of also being robbed on their way to school or at school meant some children were nervous about attending classes.

Adolescent's Health Neglect or long-term illness directly impacted on adolescents' school attendance. Many complained of headaches, symptoms of epilepsy and stomach aches and expressed concern about missing school because of their poor health. Unplanned pregnancy or early sexual debut was a reoccurring theme for many young females, often resulting in adolescent motherhood (sometimes multiple adolescent pregnancies) and subsequent immediate absence from school. 'I also got pregnant. I got a child. Out of school because there is no one who can take me to school, and there was no one who can keep my child if I am at school.' (Chuma, 20-yearold female). Limited access to transport and childcare services was seen as a barrier to school engagement. Similarly, some HIV/AIDS-orphaned adolescents were seriously injured in car accidents, therefore missing school because of hospitalisation.

Multiple Traumatic Events The trauma of losing a parent to HIV/AIDS has been well evidenced (Coombe 2002), but diminutive emphasis is placed on the further exacerbated trauma caused by additional stressful events. Several adolescents became homeless after their houses were burnt down following family arguments. 'My home was burned by my eldest brother. He used petrol. My mother burned. I went out by the window that day to survive the fire. Afterwards my mother and my sister went to hospital for three months.' (Lwazi, 18-year-old male). Female adolescents as victims of sexual abuse, perpetrated by a stranger or family member, was a reoccurring theme, and in each instance, the impact on their education was discussed. 'I was raped. I dropped out of school. I dropped out of school because I fell pregnant in February.' (Nondyedo, 19-year-old female).

After parental death, many HIV/AIDS-orphaned adolescents were separated from their siblings. This separation was described as being stressful and the breakdown of family formation and cohesion was felt to cause additional distress, which negatively affected schooling as family units dispersed.

Relocation was more traumatic if the child did not know the new foster-carer well. There was little evidence of succession planning before parental death. Multiple AIDS bereavements or familial illness and deaths from other diseases, accidents, suicides or murders also occurred in short periods. Sibling bereavement was especially challenging if the eldest sibling and head of the HIV/AIDS-orphaned household and primary breadwinner, died. They often left behind their own children, who consequently became orphans creating secondgeneration AIDS orphanhood.

\section{Protective Factors}

Happiness at School School acted as a protective environment for some, emphasising the importance of preventing school dropout. The opportunity to take part in extracurricular activities helped to build confidence and self-esteem. A supportive milieu offered an escape from their home life. The recognition of achievement was also constructive in 
their school engagement. 'I got myself a certificate. I was the best learner in Maths and Xhosa and that was at school good thing and that helped to encourage me.' (Lindinkosi, 18-yearold female).

The completion of high school was a goal expressed with tenacity and determination by nearly all the HIV/AIDSorphaned adolescents, suggesting that given the appropriate supports, most adolescents could complete secondary education and that lack of educational achievement was not the result of a lack of motivation. 'I passed matric and that was the most happiest moment after all that has happened in my life.' (Nobuhle, 17-year-old female). This determination was also expressed by adolescents who worked to save money towards their long-term goal of finishing school.

Sport was seen by many HIV/AIDS-orphaned adolescents as important in promoting their well-being and inclusion. They spoke of winning medals and trophies or recollected tournaments or races. The sense of being good at something, belonging to a team and receiving praise were all positive aspects of school life. School provided a sense of belonging especially when feelings of abandonment at home were common (Cluver \& Gardner 2007). A teacher's support and recognition of both the effects of familial AIDS and poverty were equally important in making their learner feel supported enhancing self-esteem. 'My teachers are really on my side.' (Nobuntu, 21-year-old female). In several instances the adolescents spoke of being temporarily housed by their teachers because of the turbulent situation at home. Teacher support helped in feelings of confidence and in developing new friendships and social ties. 'I met new friends in the community and at school.' (Thandeka, 18-year-old female). Social support emerged as an important resource, helping HIV/ AIDS-orphaned adolescents to settle into a new community and enabling them to build friendships at school.

Caregiving Arrangements Some HIV/AIDS-orphaned adolescents had positive caregiving experiences leading to an improvement in school absence rates. 'My aunt came to fetch me to stay with her in Cape Town because she did not like the fact that I was not sent to school.' (Thoko, 16-year-old male).

Foster-carers who treated adolescents like their own children were perceived by the learners as enabling their educational success. 'My granny was attending all the meetings at school. When I need something, granny tries by all means to help me... I am doing well at school. My life was good because of granny. She wanted me to have at least everything I need for school. Still happy at home and at school. I was passing all my grades.' (Nontando, 17-year-old female).

Grandmothers who were supportive in paying schools fees (often using their pension), attending school meetings and giving encouragement contributed to the curtailing the negative educational impacts of familial AIDS. 'My grandma is doing everything to make us not feel different from other children.' (Kwame, 19-year-old male).

Community Support Elderly members from the local community played a pivotal role in helping to feed children, often operating as the children's only external support. 'Our neighbour, sometimes she gives us food. She is old, she is not working, but when she has got something, she shares it with us.' (Duma, 14-year-old male). A few adolescents expressed that having a religious faith or belonging to a church congregation provided a continually supportive environment, especially when they did not have encouragement from caregivers or peers. 'I went to church and I felt better. Church helped me.' (Qondi, 15-year-old female).

\section{Discussion}

Overall, our findings suggest that risk factors to education parallel previous research on poverty-related factors, duty of care for AIDS-sick relatives and increasing household responsibilities. In our analysis, additional potential risk factors included adolescents as victims and perpetrators of crime and multiple teenage pregnancies all of which were contributing factors to school dropout. Examples of protective factors that were consistent with previous research included friendships with other HIV/AIDS-orphaned adolescents and grandmother support alongside emergent potential protective factors, such as extra-curricular activities and school awards.

Thematic patterns such as forced migration and forced employment were identified. These interconnecting factors of multiple risks over time led to suffering during the school day, temporary school engagement and, at worst, dropping out completely. This was exacerbated when many risk factors such as negative caregiving arrangements, substance abuse, additional traumatic events and poor adolescent health all combined to produce deleterious effects culminating in negative educational outcomes.

The overarching risk factors established were as follows: (1) Recurring household migration meant that many children were changing schools at least three to five times over a 5-year period. (2) Out-of-school adolescents appeared to be at an even higher risk of sexual abuse (Meinck et al. 2013), particularly when negative caregiving was experienced as directly hindering educational opportunity. A greater risk of sexual abuse amongst out-of-school adolescents has also been found in previous research (Meinck et al. 2013). School management, teachers and child protection services should be aware of the heightened risks of sexual abuse outside of the classroom so that it does not have a detrimental impact on adolescents' personal and school life. 
HIV/AIDS-orphaned adolescents may also be vulnerable to being involved and victimised in crime, leading to poor educational outcomes. It is important to avoid labelling, which can lead to stigma and perpetuate delinquent behaviour. Pharoah (2005) cautioned that 'labelling children as security risks, without properly understanding the nature between the AIDS epidemic and crime stands to increase stigma and discrimination'. Substance abuse was evident amongst a minority of adolescents. Meghdadpour et al. (2012) found that compared with non-orphans, paternal and double-orphaned males were more likely to have consumed alcohol, and paternally, orphaned females had significantly greater odds of drug use. Future research is encouraged to examine the intersection between substance use, delinquency and educational outcomes amongst AIDS-affected orphans.

Overall, protective factors included praise at school, teacher, caregiver, and community support and peer friendships. However, these protective factors were often not enough to keep HIV/AIDS-orphaned adolescents from leaving school prematurely. The school-protective factors appeared to be less effective when the pressures of poverty were heightened. For example, when poverty and young carer responsibilities superseded the protective effects of the supportive school environment adolescents often dropped out of school. Therefore, our results suggest that support designed to enhance educational outcomes may need to be multidimensional in order to be effective.

Exactly what predisposes South African HIV/AIDSorphaned adolescents to educational shortfalls is complex. An explanatory framework expanding Operario et al. (2008) has been designed to illustrate this complexity: multiple moves, multiple bereavement (or secondary loss ( $\mathrm{Li}$ et al. 2008) and secondary orphanhood (two generations of orphans living in the same household). This potentially growing phenomenon induced by HIV/AIDS can impact profoundly on education. Another key finding in this study is forced migration related to AIDS orphanhood as an important barrier to educational attainment. Future studies are encouraged to further examine the links between forced migration, orphanhood and education. We identified that the discontinuation of education in the adolescents' home language and broken peer and social ties due to migration both initiated substantial instability at school. Many orphans' biological fathers did not live with the family because the father had left or gone missing (some had never met their fathers). Being fatherless from birth was a commonplace (Madhavan 2004). This could increase the likelihood of intergenerational poverty because single parents may be less likely to be able to afford school fees. Therefore, understanding the complexities of the adolescents' lives before AIDS orphanhood is imperative in developing effective interventions to prevent barriers to education.

\section{Limitations}

The sample was restricted to black isiXhosa-speaking children living in high-HIV-prevalent settings in deprived environments with social instability (Ward et al. 2001). For both ethical and methodological reasons, adolescents who were going through 'acute bereavement' (0-6 months inclusive after parental death) were excluded from the study. Findings may not be generalizable to HIV/AIDS-orphaned adolescents living in rural settings, other ethnic groups or younger children. In addition, the adolescents' HIV status was not clinically tested; therefore, we could not ascertain how living with HIV and being an orphan could affect their life experiences.

Information from adolescents' responses was occasionally limited. This was possibly due to recall bias and an inaccurate memory of events or specific time points. Often, children did not attribute poor attainment to AIDS orphanhood but, instead, to the most recent traumatic event or difficulties of school subjects. The thematic content analysis conducted did not yield any frequencies of response by category and coding unit. There was no inter-coder reliability (only one coder), but the use of Nvivo as a secondary data organising tool increased reliability adding transparency to the analysis process.

\section{Strengths}

This research has a number of strengths. The qualitative methodology of the adopted IPA technique allowed for the discovery of perceptions. These qualitative findings can aid the development of culturally appropriate assessment instruments for future research ( $\mathrm{Li}$ et al. 2008). The study sample was large and varied including difficult-to-reach groups including street children and child-headed households. A wellvalidated verbal autopsy questionnaire was used to establish parental cause of death and AIDS orphan status. The research setting also created a trusting environment where many felt safe to discuss suicidal feelings or involvement in violent crimes.

To our knowledge, this research contributes to the few existing studies that explore the perceptions of secondary educational attendance of HIV/AIDS-orphaned adolescents, especially those living in high-crime disadvantaged environments in South Africa. Our findings demonstrate that there are significant risk and protective factors associated with AIDS orphanhood and secondary education. Planned interventions and policy responses should integrate orphans' perceptions and life experiences into programme design. For example, school peer support programmes could be implemented to facilitate social integration into new settings so that adolescents are given formal peer support despite having to migrate and change school settings. Such school programmes could also incorporate anti-bullying, delinquency and substance 
abuse prevention. Initiatives such as community mentor programmes could assist learners to connect their school and home life. Two of the participants interviewed had started university courses, although it was unclear what factors initiated their achievements into tertiary education. University outreach teams could visit schools to encourage learners to apply to university, giving information on bursaries.

There have been several policies launched within the new national South African Integrated School Health Programme (ISHP). This was initiated in 2011 to provide learners in schools with child support grant (CSG) and early childhood development (ECD) resources that involve linking families and young children to health (including HIV/AIDS support), education and nutrition services. The programme aims to ensure that all learners have access to primary healthcare services under the Departments of Health, Social Development and Basic Education. The policy also pays special attention to children infected or affected by HIV and AIDS who are perceived to more likely dropout of or underperform at school due to a range of psychosocial factors.

However, policy implications from these qualitative findings are speculative and must be interpreted tentatively. This research only explains HIV/AIDS-orphaned adolescents' perceptions of 'potential' risk and protective factors; subsequently, causal connections cannot be made or proven. The factors identified in the current study findings should be tested with quantitative methodologies to better understand causal relations and cumulative effects. Developing strategies to keep HIV/AIDS-orphaned adolescents in school along with monitoring their educational progress is vital. Therefore, future longitudinal studies are encouraged to examine educational opportunity at each stage of the AIDS spectrum both pre- and post-parental death.

The educational needs of AIDS-affected adolescents are an important area requiring intervention and further epidemiological research to examine the prevalence of risk and protective factors related to secondary schooling. This research highlights the importance of eliciting the views of those affected in order to design effective interventions. It is only with these nuanced and complex understandings that the multiple challenges faced by HIV/AIDS-orphaned adolescents can be understood and addressed before being positively overcome.

Acknowledgments This study was supported by grants from the Nuffield Foundation, the Regional Interagency Task team for Children Affected by Aids - Eastern and Southern Africa (RIATT-ESA) and The Economic and Social Research Council (ESRC). The authors wish to thank our fieldwork team: Somaya Latief, Naema Latief, Joy Nikelo, Julia Limba, Nomhle Panyana, Daphne Makasi and Thembela Molwana, and Prof Peter Byass and William Allen for their proof reading time. We would also like to thank Cape Town Child Welfare, the Western Cape Education Department, Pollsmoor Prison, The Homestead Shelter and
South African Airways. Most importantly, we thank all the participants and their families.

Conflict of Interest The authors declared that they had no conflicts of interest with respect to their authorship or the publication of this article. The authors have full control of the primary data and should the journal wish to review the data, it will be presented.

\section{References}

Ansell, N., \& Van Blerk, L. (2004). Children's migration as a household/ family strategy: coping with AIDS in Lesotho and Malawi. Journal of Southern African Studies, 30(3), 673-690.

Ardington, C., \& Leibbrandt, M. (2010). Orphanhood and schooling in South Africa: trends in the vulnerability of orphans between 1993 and 2005. Economic Development and Cultural Change, 58(3), 507.

Bicego, G., Rutstein, S., \& Johnson, K. (2003). Dimensions of the emerging orphan crisis in sub-Saharan Africa. Social Science \& Medicine, 56(6), 1235-1247.

Booysen, F., \& Arntz, T. (2002). Children of the storm: HIV/AIDS and children in South Africa 1. Social Dynamics, 28(1), 170-192.

Boyes, M. E., \& Cluver, L. D. (2013). Relationships among HIV/AIDS orphanhood, stigma, and symptoms of anxiety and depression in South African youth a longitudinal investigation using a path analysis framework. Clinical Psychological Science, 1(3), 323-330.

Boyes, M. E., \& Cluver, L. D. (2014). Relationships between familial HIV/AIDS and symptoms of anxiety and depression: the mediating effect of bullying victimization in a prospective sample of South African children and adolescents. Journal of youth and adolescence, $1-13$

Boyes, M. E., Cluver, L. D., \& Gardner, F. (2012). Psychometric properties of the child PTSD checklist in a community sample of South African children and adolescents. Plos One, 7(10), 1-8.

Boyes, M. E., Bowes, L., Cluver, L. D., Ward, C. L., \& Badcock, N. A. (2014). Bullying victimisation, internalising symptoms, and conduct problems in South African children and adolescents: a longitudinal investigation. Journal of Abnormal Child Psychology, 1-12.

Branson, N., Ardington, C., \& Leibbrandt, M. (2013). Trends in teenage childbearing and schooling outcomes for children born to teens in South Africa

Campbell, C., Skovdal, M., Mupambireyi, Z., \& Gregson, S. (2010). Exploring children's stigmatisation of AIDS-affected children in Zimbabwe through drawings and stories. Social Science \& Medicine, 71(5), 975-985.

Cluver, L., \& Gardner, F. (2007). Risk and protective factors for psychological well-being of children orphaned by AIDS in Cape Town: a qualitative study of children and caregivers' perspectives. AIDS Care, 19(3), 318-325.

Cluver, L., Gardner, F., \& Operario, D. (2007). Psychological distress amongst AIDS-orphaned children in urban South Africa. Journal of Child Psychology and Psychiatry, 48(8), 755-763.

Cluver, L. D., Gardner, F., \& Operario, D. (2008). Effects of stigma on the mental health of adolescents orphaned by AIDS. Journal of Adolescent Health, 42(4), 410-417.

Cluver, L., Operario, D., Gardner, F., \& Boyes, M. E. (2011). A family disease: mental health of children orphaned by AIDS and living with $\mathrm{HIV}+$ caregivers. International Perspectives on Children and Mental Health [2 Volumes], 2, 65.

Cluver, L., Operario, D., Lane, T., \& Kganakga, M. (2011). "I can't go to school and leave her in so much pain": educational shortfalls among adolescent 'young carers' in the South African AIDS epidemic. Journal of Adolescent Research, 0743558411417868 
Cluver, L. D., Orkin, M., Gardner, F., \& Boyes, M. E. (2012). Persisting mental health problems among AIDS-orphaned children in South Africa. Journal of Child Psychology and Psychiatry, 53(4), 363-370.

Coombe, C. (2002). HIV/AIDS and trauma among learners: sexual violence and deprivation in South Africa. Lifeskills within the caring professions: a career counselling perspective for the bio-technical age. Cape Town: Heinemann Educational Publishers.

Duffy, L. (2005). Suffering, shame, and silence: the stigma of HIV/AIDS. Journal of the Association of Nurses in AIDS Care, 16(1), 13-20.

Edmonds, E. V. (2006). Child labor and schooling responses to anticipated income in South Africa. Journal of Development Economics, 81(2), 386-414.

Foster, G. (2006). Children who live in communities affected by AIDS. The Lancet, 367(9511), 700-701.

Gavin, L., Galavotti, C., Dube, H., McNaghten, A., Murwirwa, M., Khan, R., et al. (2006). Factors associated with HIV infection in adolescent females in Zimbabwe. Journal of Adolescent Health, 39(4), 596. e511-596. e518.

Guo, Y., Li, X., \& Sherr, L. (2012). The impact of HIV/AIDS on children's educational outcome: a critical review of global literature. AIDS Care, 24(8), 993-1012.

Hosegood, V., Vanneste, A.-M., \& Timæus, I. M. (2004). Levels and causes of adult mortality in rural South Africa: the impact of AIDS. AIDS, 18(4), 663-671.

Hunter, S. S., \& Williamson, J. (2000). Children on the brink: strategies to support a generation isolated by HIV/AIDS: United States Agency for International Development

Kahn, K., Tollman, S. M., Garenne, M., \& Gear, J. S. (2000). Validation and application of verbal autopsies in a rural area of South Africa. Tropical Medicine \& International Health, 5(11), 824-831.

Lachman, J. M., Cluver, L. D., Boyes, M. E., Kuo, C., \& Casale, M. (2013). Positive parenting for positive parents: HIV/AIDS, poverty, caregiver depression, child behavior, and parenting in South Africa. AIDS Care(ahead-of-print), 1-10.

Li, X., Naar-King, S., Barnett, D., Stanton, B., Fang, X., \& Thurston, C. (2008). A developmental psychopathology framework of the psychosocial needs of children orphaned by HIV. Journal of the Association of Nurses in AIDS Care, 19(2), 147-157.

Madhavan, S. (2004). Fosterage patterns in the age of AIDS: continuity and change. Social Science \& Medicine, 58(7), 1443-1454.

Masanjala, W. (2007). The poverty-HIV/AIDS nexus in Africa: a livelihood approach. Social Science \& Medicine, 64(5), 1032-1041.

Meghdadpour, S., Curtis, S., Pettifor, A., \& MacPhail, C. (2012). Factors associated with substance use among orphaned and non-orphaned youth in South Africa. Journal of Adolescence, 35(5), 1329-1340.

Meinck, F., Cluver, L. D., Boyes, M. E., \& Ndhlovu, L. D. (2013). Risk and protective factors for physical and emotional abuse victimisation amongst vulnerable children in South Africa. Child Abuse Review

Moleni, C. M. (2008). Factors influencing access and retention in primary schooling for children and young people affected by HIV and AIDS: case studies from rural Malawi. Institute of Education, University of London, SOFIE Opening Up Access Series(6).

Murray, C. J. S. (2010). Collaborative community-based care for South African children orphaned by HIV/AIDS. Journal for Specialists in Pediatric Nursing, 15(1), 88-92.

Odhiambo, W. (2003). HIV/AIDS and debt crises: threat to human survival in sub-Saharan Africa*. Medicine, Conflict, and Survival, 19(2), 142-147.

Operario, D., Cluver, L., Rees, H., MacPhail, C., \& Pettifor, A. (2008). Orphanhood and completion of compulsory school education among young people in South Africa: findings from a national representative survey. Journal of Research on Adolescence, 18(1), 173-186.

Orkin, M., Boyes, M. E., Cluver, L. D., \& Zhang, Y. (2014). Pathways to poor educational outcomes for HIV/AIDS-affected youth in South Africa. AIDS Care, 26(3), 343-350.

Petersen, I., Bhana, A., Myeza, N., Alicea, S., John, S., Holst, H., et al. (2010). Psychosocial challenges and protective influences for socioemotional coping of HIV+ adolescents in South Africa: a qualitative investigation. AIDS Care, 22(8), 970-978.

Pharoah, R. (2005). AIDS, orphans and crime. SA crime quarterly(13).

Richter, L. (2004). The impact of HIV/AIDS on the development of children. A generation at risk, 9-31

Ritchie, J., \& Lewis, J. (2003). Qualitative research practice: a guide for social science students and researchers: Sage

Skovdal, M., Ogutu, V. O., Aoro, C., \& Campbell, C. (2009). Young carers as social actors: coping strategies of children caring for ailing or ageing guardians in Western Kenya. Social Science \& Medicine, 69(4), 587-595.

Smith, J. A. (2007). Qualitative psychology: a practical guide to research methods: Sage

Smith, J., \& Firth, J. (2011). Qualitative data analysis: the framework approach. Nurse Researcher, 18(2), 52.

StatsSA (2011). Statistics South Africa-Census 2011

Takizawa, R., Maughan, B., \& Arseneault, L. (2014). Adult health outcomes of childhood bullying victimization: evidence from a five-decade longitudinal British birth cohort. American Journal of Psychiatry, 171, 777-778.

UNAIDS (2013). Children and AIDS. Sixth stocktaking report: towards an AIDS free generation

UNAIDSa (2013). Global report: UNAIDS report on the global AIDS epidemic

UNICEF (2011). Taking evidence to impact: making a difference for vulnerable children living in a world with HIV and AIDS.

Van Blerk, L., \& Ansell, N. (2006). Children's experiences of migration in Southern Africa: moving in the wake of AIDS. Environment and Planning D-Society and Space, 24(3), 449-471.

Ward, C., Flisher, A., Zissis, C., Muller, M., \& Lombard, C. (2001). Adolescents' exposure to violence: relationships between exposure and symptoms. Injury Prevention, 7, 297-301. 